\title{
Solvent-free synthesis of SAPO-5 zeolite with plate-like morphology in the presence of surfactants
}

\author{
Xian Chen, Xiangju Meng *, Feng-shou Xiao \\ Key Lab of Applied Chemistry of Zhejiang Province, Department of Chemistry, Zhejiang University, Hangzhou 310007, Zhejiang, China
}

\section{A R T I C L E I N F O}

Article history:

Received 27 November 2014

Accepted 30 December 2014

Published 20 June 2015

\section{Keywords:}

Solvent-free synthesis

AFI structure

Plate-like morphology

Surfactant

\begin{abstract}
A B S T R A C T
SAPO-5 crystals with plate-like morphology were synthesized in the presence of surfactants such as cetyltrimethyl ammonium bromide under solvent-free conditions. X-ray diffraction patterns and scanning electron microscopy images revealed that the samples had high crystallinity and controllable plate-like morphology. The amount of surfactant added played an important role in controlling the thickness of the zeolite crystals. Considering the unique one-dimensional microporous architecture of AFI, SAPO-5 crystals with unique plate-like morphology are expected to be of great importance in catalytic applications.
\end{abstract}

(C) 2015, Dalian Institute of Chemical Physics, Chinese Academy of Sciences. Published by Elsevier B.V. All rights reserved.
Microporous crystalline aluminophosphate-based zeolites, a zeolite family first discovered in the early 1980s [1,2], have been widely applied in catalysis, adsorption, and separation [3-5]. Notably, their syntheses are generally performed under hydrothermal conditions, where a large amount of water or alcohol is necessary [6-9]. The use of such solvents not only produces waste, but also reduces synthetic efficiency and generates high pressure in the autoclaves used. Many sustainable routes have been designed to solve these solvent problems [10-13]. For example, the ionothermal synthesis of APO-11 and APO-5 has been performed by two independent research groups, those of Cooper et al. [11] and Wang et al. [12]. This method completely avoids the need for high pressure autoclaves. In our group, the solvent-free synthesis of SAPO-34 and SAPO-11 zeolites has been designed, a method which both reduces the amount of solvent waste and significantly increases the zeolite product yield [13].

It has been reported that the morphology of a zeolite strongly influences its catalytic properties [14-17]. For example, Choi et al. [14] reported that zeolite nanosheets were active and long-lived catalysts; Seo et al. [15] showed that ZSM-5 crystals with long $b$-axis length exhibited improved $p$-xylene selectivity in $m$-xylene isomerization; Kodaira et al. [16] reported a new aluminophosphate phase with a bellows-like morphology; Yang et al. [9] fabricated SAPO-5 crystals with a novel hexagonal pencil-like morphology. Wu et al. [17] reported that SAPO-34 molecular sieve samples with sheet-like and cubic morphology were synthesized under microwave and hydrothermal conditions, and exhibited longer stability and higher olefin selectivity over methanol. Notably, these zeolites with unique morphology were synthesized under hydrothermal conditions. Here, we demonstrate a plate-like morphological control of SAPO-5 zeolite in the presence of surfactants under solvent-free conditions. The ability to control the morphology of zeolite crystals through our solvent-free route is expected to be helpful to improve their catalytic properties.

The solvent-free synthesis of SAPO-5 with plate-like morphology was performed by grinding solid compounds at room temperature and heating to $200{ }^{\circ} \mathrm{C}$ in the presence of cetyltrimethyl ammonium bromide (CTAB). In a typical run,

* Corresponding author. Tel: +86-571-88273698; E-mail: mengxj@zju.edu.cn 
$0.785 \mathrm{~g}$ of di- $n$-propylamine phosphate (DPA $\left.\cdot \mathrm{H}_{3} \mathrm{PO}_{4}\right), 0.364 \mathrm{~g}$ of boehmite, $0.8 \mathrm{~g}$ tetraethylammonium bromine (TEABr), $0.036 \mathrm{~g}$ fumed silica, and a required amount of CTAB were mixed. After grinding for 15-30 min, the mixture was transferred into an autoclave and heated at $200{ }^{\circ} \mathrm{C}$ for $36-48 \mathrm{~h}$. The product, designated S-SAPO-5-CTAB, was finally obtained by filtration, washing with deionized water, drying at $100^{\circ} \mathrm{C}$, and calcination at $550{ }^{\circ} \mathrm{C}$ for $5 \mathrm{~h}$. The solvent-free synthesis of the zeolite product in the absence of CTAB (designated S-SAPO-5) was also performed.

X-ray powder diffraction (XRD) patterns were measured with a Rigaku Ultimate VI X-ray diffractometer $(40 \mathrm{kV}, 40 \mathrm{~mA})$ using $\mathrm{Cu} K_{\alpha}(\lambda=1.5406 \AA)$ radiation. Scanning electron microscopy (SEM) analyses were performed on a Hitachi S-1510 electron microscope.

Figure 1 shows the XRD patterns of S-SAPO- 5 in the absence or presence of CTAB. All samples exhibited a series of well-resolved characteristic and strong peaks associated with the AFI structure [12], suggesting their high crystallinity. Notably, the spectra also had quite distinguishable peak intensities at $19.74^{\circ}$ and $20.97^{\circ}$, assigned to (210) and (002) reflections, respectively. When the solvent-free synthesis was performed without $\mathrm{CTAB}$, the peak at $19.74^{\circ}$ was much weaker than that at $20.97^{\circ}$. When $\mathrm{CTAB}$ was added $\left(\mathrm{CTAB} / \mathrm{Al}_{2} \mathrm{O}_{3}\right.$ ratio of 0.015 ), the intensity of the peak at $20.97^{\circ}$ was significantly reduced; an increase in the $\mathrm{CTAB} / \mathrm{Al}_{2} \mathrm{O}_{3}$ ratio to 0.24 led to the peak at $19.74^{\circ}$ becoming much stronger in intensity than the peak at $20.97^{\circ}$. These results indicate that the addition of the CTAB strongly influenced the growth of the SAPO-5 crystals in the (002) direction.

Figure 2 shows SEM images of S-SAPO-5 synthesized with various amounts of CTAB. When the synthesis was absent of $\mathrm{CTAB}$, the product morphology was spherical. When a small amount of $\mathrm{CTAB}$ was added $\left(\mathrm{CTAB} / \mathrm{Al}_{2} \mathrm{O}_{3}\right.$ ratio at 0.015$)$ the zeolite became discus-like. At a $\mathrm{CTAB} / \mathrm{Al}_{2} \mathrm{O}_{3}$ ratio of 0.03 , the morphology of the zeolite became plate-like with thickness of about $200 \mathrm{~nm}$. A similar morphology was obtained at a higher $\mathrm{CTAB} / \mathrm{Al}_{2} \mathrm{O}_{3}$ ratio of 0.24 , but the plate thickness was greatly

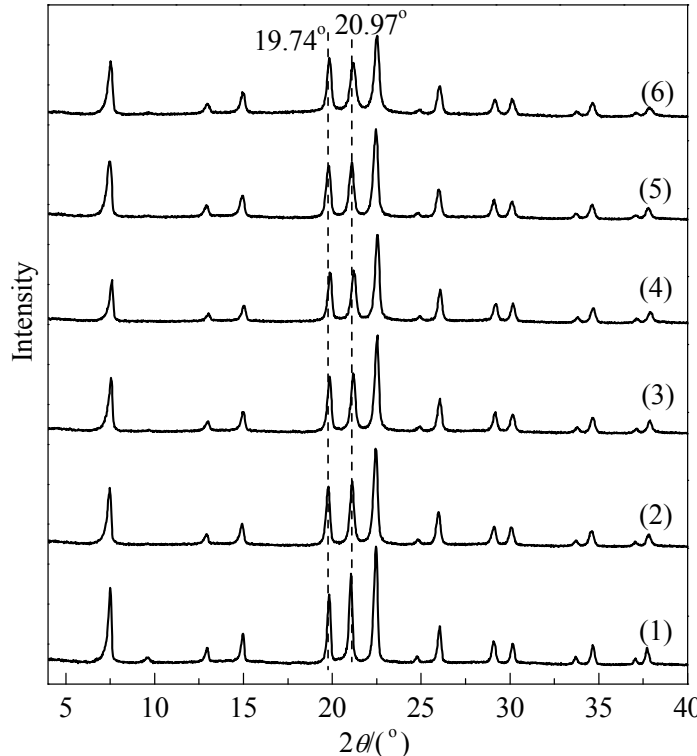

Fig. 1. XRD patterns of S-SAPO- 5 synthesized with different $\mathrm{CTAB} / \mathrm{Al}_{2} \mathrm{O}_{3}$ ratios of (1) 0 , (2) 0.015, (3) 0.03, (4) 0.06, (5) 0.12, and (6) 0.24 .

reduced to $50-70 \mathrm{~nm}$.

Obviously, the presence of CTAB in the solvent-free synthesis strongly influenced the zeolite morphology.

Generally, surfactants such as CTAB are typical templates for the synthesis of ordered mesoporous materials such as MCM-41, where the surfactant micelles present in the water direct the formation of meso-structure. However, in the solvent-free synthesis, the formation of micelles is difficult owing to the absence of water. Therefore, we cannot explain this phenomenon in terms of the formation of surfactant micelles in the solvent-free synthesis. One possibility is that the surfactant molecules might selectively adsorb onto certain surfaces of the zeolite crystals, hindering growth at those surfaces. As observed in Fig. 1, the (002) direction of the SAPO-5 crystals was strongly suppressed after the addition of CTAB to the solvent-free synthesis, confirming this suggestion.
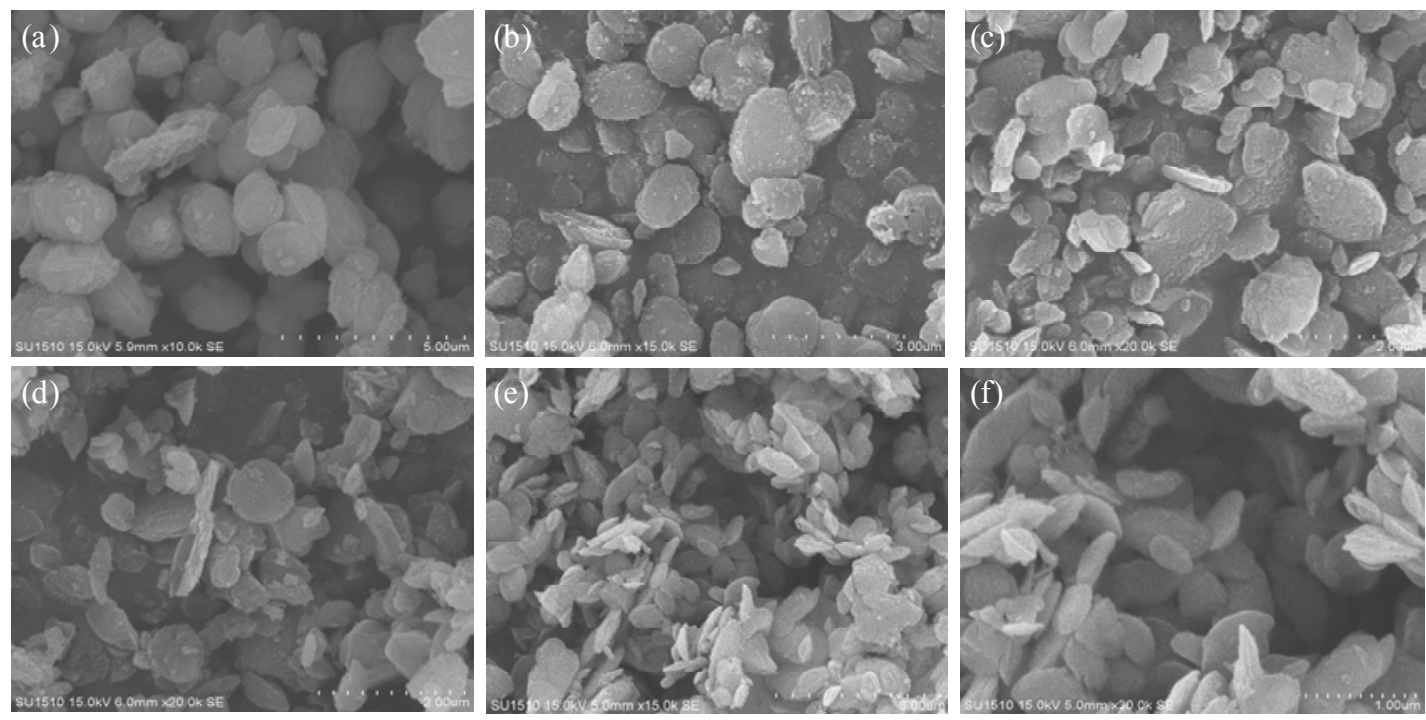

Fig. 2. SEM images of S-SAPO-5 synthesized with different $\mathrm{CTAB} / \mathrm{Al}_{2} \mathrm{O}_{3}$ ratios of (a) 0, (b) 0.015, (c) 0.03, (d) 0.06, (e) 0.12, and (f) 0.24 . 


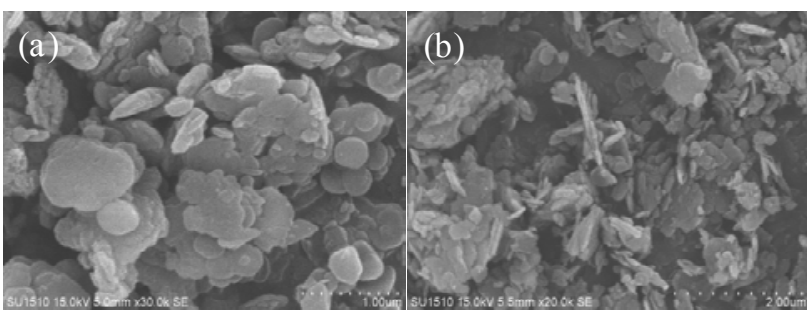

Fig. 3. SEM images of S-SAPO-5 synthesized in the presence of F127 (a) and glucose (b). The ratio of $\mathrm{F} 127$ or glucose to $\mathrm{Al}_{2} \mathrm{O}_{3}$ was 0.015 .

As a result, plate-like crystals of SAPO-5 were finally obtained.

Figure 3 shows SEM images of S-SAPO- 5 synthesized in the presence of F127 and glucose. Clearly, both products also had plate-like morphology. These results indicate that the plate-like morphology of SAPO- 5 was not only limited to the use of CTAB, and many additives might be suitable.

CTAB was also used to adjust the morphology of APO-11 crystals. Figure 4 shows XRD patterns and SEM images of solvent-free synthesized APO-11 zeolites in the absence and presence of CTAB. Interestingly, when the synthesis was absent of CTAB, the product S-APO-11 was spherical, while a plate-like product S-APO-11-CTAB morphology was obtained when the CTAB was added. Thus, CTAB also played an important role in controlling the morphology of APO-11 synthesized under solvent-free conditions.

In summary, SAPO-5 crystals with plate-like morphology were successfully synthesized in the presence of CTAB under solvent-free conditions. Most importantly, the use of surfactants to control product morphology in our solvent-free synthesis method may be extended to the synthesis of other zeolites such as APO-11. The present approach is expected to be favorable for designing and preparing highly active zeolite catalysts.

\section{References}

[1] Wilson S T, Lok B M, Messina C A, Cannan T R, Flanigen E M. J Am Chem Soc, 1982, 104: 1146

[2] Davis M E, Saldarriaga C, Montes C, Garces J, Crowdert C. Nature, 1988, 331: 698

[3] Feng P Y, Bu X H, Stucky G D. Nature, 1997, 388: 735

[4] Davis M E. Nature, 2002, 417: 813

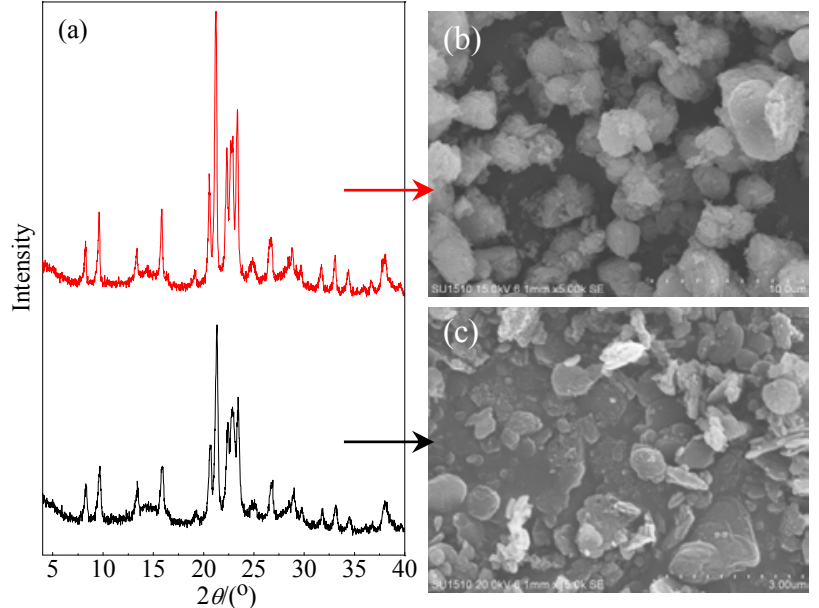

Fig. 4. XRD patterns (a) and SEM images (b, c) of S-APO-11 synthesized in the absence (b) and presence (c) of CTAB. The $\mathrm{CTAB} / \mathrm{Al}_{2} \mathrm{O}_{3}$ ratio was 0.015 .

[5] Yuan C Y, Wei Y X, Xu L, Li J Z, Xu S T, Zhou Y, Chen J R, Wang Q Y, Liu Z M. Chin J Catal (袁翠峪, 魏迎旭, 许否, 李金哲, 徐舒涛, 周 游, 陈景润, 王全义, 刘中民. 催化学报), 2012, 33: 768

[6] Qiu S L, Pang W Q, Kessler H, Guth J L. Zeolites, 1989, 9: 440

[7] Girnus I, Pohl M M, Richter-Mendau J, Schneider M, Noack M, Venzke D, Caro J. Adv Mater, 1995, 7: 711

[8] Fan W B, Li R F, Dou T, Tatsumi T, Weckhuysen B M. Microporous Mesoporous Mater, 2005, 84: 116

[9] Yang Q, Li M, Zeng C, Zhang L. Chem Eur J, 2013, 19: 365

[10] Bandyopadhyay M, Bandyopadhyay R, Kubota Y, Sugi Y. Chem Lett, 2000, 29: 1024

[11] Cooper E R, Andrews C D, Wheatley P S, Webb P B, Wormald P, Morris R E. Nature, 2004, 430: 1012

[12] Wang L, Xu Y P, Wei Y, Duan J C, Chen A B, Wang B C, Ma H J, Tian Z J, Lin L W. J Am Chem Soc, 2006, 128: 7432

[13] Jin Y Y, Sun Q Qi G D, Yang C G, Xu J, Chen F, Meng X Q, Deng F, Xiao F S. Angew Chem Int Ed, 2013, 52: 9172

[14] Choi M, Na K, Kim J, Sakamoto Y, Terasaki O, Ryoo R. Nature, 2009, 461: 246

[15] Seo Y, Lee S, Jo C, Ryoo R. J Am Chem Soc, 2013, 135: 8806

[16] Kodaira T, Nabata A, Ikeda T. Microporous Mesoporous Mater, 2012, 162: 31

[17] Lei W, Liu Z Y, Xia L, Qiu M H, Liu X, Zhu H J, Sun Y H. Chin J Catal (吴否, 刘子玉, 夏林, 丘明煌, 刘旭, 朱浩佳, 孙予罕. 催化学报), 2013, 34: 1348

\section{Graphical Abstract}

Chin. J. Catal., 2015, 36: 797-800 doi: 10.1016/S1872-2067(14)60285-0

\section{Solvent-free synthesis of SAPO-5 zeolite with plate-like morphology in the presence of surfactants}

Xian Chen, Xiangju Meng*, Feng-shou Xiao Zhejiang University

SAPO-5 crystals with plate-like morphology were synthesized in the presence of surfactants such as CTAB under solvent-free conditions. Such zeolite crystals with unique plate-like morphology are expected to be of great importance in catalytic applications.

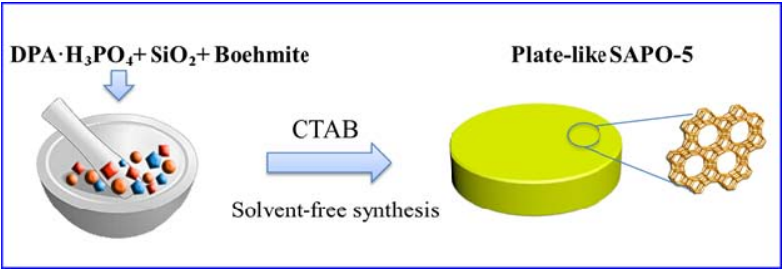




\title{
无溶剂合成SAPO-5沸石中表面活性剂对其片状形貌的控制
}

\author{
陈 鲜, 孟祥举*, 肖丰收 \\ 浙江大学化学系浙江省应用化学重点实验室, 浙江杭州 310028
}

摘要: 在表面活性剂如十六烷基三甲基澳化铵(CTAB)的存在下, 采用无溶剂法合成出具有片状形貌的SAPO-5沸石晶体. X射线 衍射和扫描电镜结果表明, 所合成的样品具有很好的结晶度和可控的片状形貌, 在合成过程中, CTAB的添加量对其片状形貌特 别是片状的厚度的影响很大. 考虑到一维的微孔AFI结构独特, 具有特殊片状形貌的SAPO-5晶体有望应用于催化方面.

关键词: 无溶剂合成; AFI结构; 片状形貌; 表面活性剂

收稿日期: 2014-11-27. 接受日期: 2014-12-30. 出版日期: 2015-06-20.

*通讯联系人. 电话: (0571)88273698; 电子信箱: mengxj@zju.edu.cn

本文的英文电子版由Elsevier出版社在ScienceDirect上出版(http://www.sciencedirect.com/science/journal/18722067). 